\title{
Development and psychometric properties of a belief-based Physical Activity Questionnaire for Diabetic Patients (PAQ-DP)
}

\author{
Zeinab Ghazanfari ${ }^{1,2}$, Shamsaddin Niknami ${ }^{1 *}$, Fazlollah Ghofranipour ${ }^{1}$, Ebrahim Hajizadeh ${ }^{3}$, Ali Montazeri ${ }^{4}$
}

\begin{abstract}
Background: This study carried out to develop a scale for assessing diabetic patients' perceptions about physical activity and to test its psychometric properties (The Physical Activity Questionnaire for Diabetic Patients-PAQ-DP).

Methods: An item pool extracted from the Theory of Planned Behavior literature was generated. Then an expert panel evaluated the items by assessing content validity index and content validity ratio. Consequently exploratory factor analysis (EFA) was performed to indicate the scale constructs. In addition reliability analyses including internal consistency and test-retest analysis were carried out.

Results: In all a sample of 127 women with diabetes participated in the study. Twenty-two items were initially extracted from the literature. A six-factor solution (containing 19 items) emerged as a result of an exploratory factor analysis namely: instrumental attitude, subjective norm, perceived behavioral control, affective attitude, self-identity, and intention explaining $60.30 \%$ of the variance observed. Additional analyses indicated satisfactory results for internal consistency (Cronbach's alpha ranging from 0.54 to 0.8 ) and intraclass correlation coefficients (ranging from 0.40 to 0.92 ).

Conclusions: The Physical Activity Questionnaire for Diabetic Patients (PAQ-DP) is the first instrument that applies the Theory of Planned Behavior in its constructs. The findings indicated that the PAQ-DP is a reliable and valid measure for assessing physical activity perceptions and now is available and can be used in future studies.
\end{abstract}

\section{Background}

Diabetes mellitus (DM) is an increasingly global public health problem. The number of people (aged 20-79 years) affected by diabetes in world will increase from 6.4\% (285 million adults) in 2010 to $7.7 \%$, (439 million adults) by 2030 . This increase will be $69 \%$ in developing countries while developed countries will experience a $20 \%$ increase during the same period [1].

Physical activity reduces the risk of over 25 chronic conditions, in particular, coronary heart disease, stroke, hypertension, breast cancer, colon cancer, osteoporosis, and type 2 diabetes [2]. Regular physical activity is recommended for type 2 diabetic patients, as it is commonly known to correct metabolic disorders and prevent complications such as cardiovascular diseases [3].

\footnotetext{
* Correspondence: niknamis@modares.ac.ir

'Department of Health Education, Tarbiat Modares University, Tehran, Iran Full list of author information is available at the end of the article
}

The Canadian Diabetes Association's (CDA) Clinical Practice Guidelines for the prevention and management of diabetes recommended that type 2 diabetic patients should participate in moderate-intensity physical activity, such as brisk walking and biking, for at least 150 minutes/week, over at least 3 nonconsecutive days [4]. However recent studies have shown that diabetic patients may undertake less physical activity than nondiabetic people. Up to one third of diabetic patients are completely sedentary, and only a third exercise regularly [5]. To change this to a more healthy behavior the need for theory-driven interventions are recommended [6,7]. Theory provides a road map for studying problems, developing appropriate interventions, and evaluating their successes. Theory can also help planners identify the most suitable target audiences, methods for fostering change, and outcomes for evaluation [6]. The Theory of Planned Behavior (TPB) [8] is a well-established theory that has been used to further understand predictive

Full tist of author information is available at the end of the article

(c) 2010 Ghazanfari et al; licensee BioMed Central Ltd. This is an Open Access article distributed under the terms of the Creative Commons Attribution License (http://creativecommons.org/licenses/by/2.0), which permits unrestricted use, distribution, and reproduction in any medium, provided the original work is properly cited. 
factors of health behaviors in general $[9,10]$ and physical activity in particular [11-14]. Numerous studies have provided support for the TPB to explain why some people practice physical activity and some do not [15-19].

This theory suggests that people's intention to perform a specific behavior is predicted or influenced by three determinants: attitudes, subjective norms and perceived behavioral control. Attitude refers to a personal factor of like or dislike, subjective norms refers to an individual's perception of social pressure, and perceived behavioral control refers to a person's perceived confidence in the ability to perform a behavior [20]. Hagger et al. reviewed 79 studies in a meta-analysis and reported that the TPB explained $44.5 \%$ of the variance in physical activity intentions and $27.4 \%$ of the variance in physical activity behavior [14].

The application of TPB in studies of physical activity in diabetic patients are well documented. For instance Plotnicoff et al. in a study on diabetic patients found the TPB constructs explained almost $40 \%$ of the variance in intentions for type 1 and type 2 diabetes. In crosssectional studies, the TPB accounted for 23 and 19\% of the variance in PA for type 1 and type 2 diabetes, respectively. In prospective studies, the TPB explained 13 and $8 \%$ of the variance in PA for type 1 and type 2 diabetes, respectively. The findings provide evidence for the utility of the TPB for the design of PA promotion interventions for adults with either type 1 or type 2 diabetes [21]. Also Davies et al. found that intention explained $28 \%$ of the variance in physical activity behavior. Attitude, subjective norm and perceived behavioral control (PBC) explained 73\% of variance in physical activity intention. Attitude and $\mathrm{PBC}$ mediated the relationship between conscientiousness and physical activity intention. These results showed that targeting constructs proximal to the behavior (attitudes and $\mathrm{PBC}$ ) may be effective in overcoming inherent qualities such as personality in order to produce physical activity behavior change within this sample population [22]. Data show links between sedentary behavior and all-cause mortality, cardiovascular disease, obesity, and adverse metabolic profiles [23]. Preliminary findings from STIL Project suggest that inactivity is more complex than we sometimes think [24]. Thus, in order to develop effective interventions to promote habitual physical activity, the predictive factors of this behavior is needed to be identified [25].

At present there are no comprehensive validated scales for measuring diabetic patients' beliefs regarding physical activity. Such instruments could help to understand patients' perspectives and in turn design comprehensive interventional programs for diabetic patients. Available instruments review particular aspects of the beliefs such as perceived benefits and barriers [26-31], outcome expectancy [29-32], self-efficacy [30,33], social support $[29,30]$, enjoyment of physical activity $[29,30]$, social influences [33], that were developed in the framework of other health belief models. There was one more questionnaire, developed by Blue et al., assesses the indirect measures of the theory of planned behavior including behavioral beliefs, normative beliefs and control beliefs to predict physical activity intentions of persons at risk for diabetes [34]. No questionnaire was found in the context of direct measures of the Theory of Planned Behavior. The main objective of this study was to design and develop an instrument in such a framework. However, this study included an additional construct (self-identity) to the original theory. As Ajzen suggests the Theory of Planned Behavior is open for further extension with additional constructs [35]. Studies have shown that individuals who identify themselves as exercisers have more favorable intentions and engage significantly more in exercise than those who do not [36-38]. It is argued that self-identity may play an important role in predicting physical activity [36-38]. Furthermore, this study was limited to a sample of female diabetic patients. It is estimated that more than 1.5 million people with diabetes live in Iran. The preliminary results derived from a national study indicated that the prevalence of type 2 diabetes was $3.6 \%$ among adults aged over 30 (4.3\% of women and $2.6 \%$ of men) [39]. The figures clearly indicate that, as many other countries, women in Iran are suffering more from diabetes. In addition, the existing data from Iran indicate that prevalence of sedentary lifestyle in females is higher than males [40-42]. Sarrafzadegan et al. found that abdominal obesity was nearly six times as prevalent in women as in men $(71.7 \%$ vs. $12 \%, \mathrm{P}<0.05)$ [43].

\section{Methods}

\section{Definition and measure}

Physical activity was defined as activities with moderate intensity, at least 3 or more times per week, accumulating at least 150 minutes per week derived from Health Canada's position stand for recommended weekly exercise among diabetic adults [4]. Physical activity was assessed by the Seven Day Physical Activity Recall Questionnaire $[44,45]$.

\section{Scale development}

First, we generated an item pool extracted from the literature [25,46-68] relating to the Theory of Planned Behavior (Table 1). The initial scale consisted of 22 items. Each item was rated on a 5-point Likert scale anchored at 1 to 5 (strongly agree to strongly disagree, very likely to very unlikely, very beneficial to very harmful, very worthwhile to very worthless, very good to very bad, very enjoyable to very boring, very 
Table 1 The list of papers for generating item pool (derived from Theory of Planned Behavior (TPB) literature)

\begin{tabular}{|c|c|c|c|}
\hline Author(s) & Year & $\begin{array}{l}\text { No. of } \\
\text { items }\end{array}$ & Constructs \\
\hline $\begin{array}{l}\text { Courneya, et al. } \\
\text { [46] }\end{array}$ & 1998 & 16 & Attitude, subjective norm, perceived behavioral control, intention \\
\hline $\begin{array}{l}\text { Courneya et al. } \\
\text { [47] }\end{array}$ & 1999 & 15 & Attitude, subjective norm, perceived behavioral control, intention \\
\hline $\begin{array}{l}\text { Courneya, \& Bobick } \\
{[48]}\end{array}$ & 2000 & 17 & Attitude, subjective norm, perceived behavioral control, intention \\
\hline Blue, et al [49] & 2001 & 12 & Attitude, subjective norm, perceived behavioral control, behavioral, normative and control beliefs, intention \\
\hline Jackson, et al. [25] & 2003 & 27 & $\begin{array}{l}\text { Attitude, subjective norm, perceived behavioral control, intention, descriptive norm, personal norm (moral } \\
\text { norm and anticipated affective reaction), self-identity, past behavior }\end{array}$ \\
\hline $\begin{array}{l}\text { Rhodes, \& } \\
\text { Courneya [50] }\end{array}$ & 2003 & 13 & Attitude, subjective norm, perceived behavioral control, intention \\
\hline Francis, et al [51] & 2004 & 26 & $\begin{array}{l}\text { Attitude (instrumental, affective), subjective norm (injunctive, descriptive), perceived behavioral control (self- } \\
\text { efficacy, controllability), behavioral, normative and control beliefs, intention (generalized, statement) }\end{array}$ \\
\hline $\begin{array}{l}\text { Hausenblas, \& } \\
\text { Downs [52] }\end{array}$ & 2004 & 13 & Attitude, subjective norm, perceived behavioral control, intention \\
\hline $\begin{array}{l}\text { Rhodes, \& } \\
\text { Courneya [53] }\end{array}$ & 2004 & 21 & Attitude, subjective norm, perceived behavioral control, intention \\
\hline $\begin{array}{l}\text { Prapavessis, et al. } \\
{[54]}\end{array}$ & 2005 & 19 & Attitude, subjective norm, perceived behavioral control, intention \\
\hline $\begin{array}{l}\text { Rhodes, \& } \\
\text { Plotnikoff [55] }\end{array}$ & 2005 & 9 & Attitude, subjective norm, perceived behavioral control, intention \\
\hline Walsh, et al. [56] & 2005 & 11 & Attitude, subjective norm, perceived behavioral control, intention \\
\hline Ajzen I [57] & 2006 & 26 & $\begin{array}{l}\text { Attitude (instrumental, affective), subjective norm (injunctive, descriptive), perceived behavioral control } \\
\text { (capability, controllability), behavioral, normative and control beliefs, intention }\end{array}$ \\
\hline $\begin{array}{l}\text { Courneya, et al. } \\
\text { [58] }\end{array}$ & 2006 & 21 & Instrumental and affective attitudes, injunctive and descriptive norms, perceived control, intention \\
\hline Kaiser [59] & 2006 & 12 & Attitude, subjective norm, perceived behavioral control, intention \\
\hline White, et al. [60] & 2007 & 14 & Behavioral, normative and control beliefs \\
\hline Hill, et al. [61] & 2007 & 9 & Attitude, normative beliefs, perceived behavioral control, intention \\
\hline Blue [62] & 2007 & 45 & Attitude, subjective norm, perceived behavioral control, intention, behavioral, normative and control beliefs \\
\hline Jones, et al. [63] & 2007 & 14 & Attitude, subjective norm, perceived behavioral control, intention \\
\hline $\begin{array}{l}\text { Plotnikoff, et al. } \\
\text { [64] }\end{array}$ & 2008 & 14 & Attitude, subjective norm, perceived behavioral control, intention \\
\hline Parrott, et al. [65] & 2008 & 12 & Instrumental and affective attitudes, subjective norm, perceived behavioral control, intention \\
\hline $\begin{array}{l}\text { Chatzisarantis, et al. } \\
\text { [66] }\end{array}$ & 2008 & 14 & Attitudes, subjective norms, perceived behavioral control, intention \\
\hline $\begin{array}{l}\text { Boudreau, \& Godin } \\
\text { [67] }\end{array}$ & 2009 & 45 & $\begin{array}{l}\text { Attitude, subjective norm, perceived behavioural control, intention, behavioural beliefs, normative beliefs, } \\
\text { control beliefs, anticipated regret, moral norm, descriptive norm }\end{array}$ \\
\hline
\end{tabular}

relaxing to very stressful, strongly satisfied to strongly unsatisfied) Table 2.

Subsequently an expert panel of 10 specialists in health education, diabetes, and physical education examined the initial questionnaire. The panel was asked to comment on individual items in relation to the accuracy, clarity, and style. Items were slightly modified based on expert reviews. Then, a different panel of 11 experts on health education was asked to comment independently on necessity and relevance of the items in order to calculate Content Validity Ratio (CVR) and Content Validity Index (CVI), respectively. The necessity of the items was assessed using a three-point rating scale: (i) not necessary, (ii) useful, but not essential, (iii) essential. Following the experts' assessments, a CVR for total scale was computed. According to Lawshe, if more than half of the panelists indicate that an item is essential, that item has at least content validity [69]. The CVR in this study for total scale was .61 indicating a satisfactory result. The relevance of the items was also assessed using a four-point rating scale: (i) not relevant, (ii) slightly relevant, (iii) relevant, and (iv) very relevant. The CVI of each question is the proportion of experts who rate it as 3 or 4 [70]. Polite and Beck recommended 0.80 for the acceptable lower limit for CVI value [71]. A satisfactory level of agreement was found $(\mathrm{CVI}=0.91)$ 
Table 2 The PAQ-DP items extracted from the literature in the context of Theory of Planned Behavior

\begin{tabular}{|c|c|c|}
\hline & Item Pools & Response categories \\
\hline 1 & Doing 30 minutes of moderate physical activity at least 5 days a week would be ..... & $\begin{array}{l}\text { Very beneficial - beneficial - neither beneficial nor } \\
\text { harmful - harmful - very harmful }\end{array}$ \\
\hline 2 & Doing 30 minutes of moderate physical activity at least 5 days a week would be .... & $\begin{array}{l}\text { Very worthwhile - worthwhile - neither worthwhile nor } \\
\text { worthless - worthless - very worthless }\end{array}$ \\
\hline 3 & Doing 30 minutes of moderate physical activity at least 5 days a week would be ..... & $\begin{array}{l}\text { Very good - good - neither good nor bad - bad - very } \\
\text { bad }\end{array}$ \\
\hline 4 & Doing 30 minutes of moderate physical activity at least 5 days a week would be ..... & $\begin{array}{l}\text { Very enjoyable- enjoyable -neither enjoyable nor boring } \\
\text { - boring -very boring }\end{array}$ \\
\hline 5 & Doing 30 minutes of moderate physical activity at least 5 days a week would be ..... & $\begin{array}{l}\text { Very relaxing - relaxing - neither relaxing nor stressful - } \\
\text { stressful - very stressful }\end{array}$ \\
\hline 6 & $\begin{array}{l}\text { People who are important to me think I should do } 30 \text { minutes of moderate physical } \\
\text { activity at least } 5 \text { days a week. }\end{array}$ & $\begin{array}{l}\text { Strongly agree - agree - neither agree nor disagree - } \\
\text { disagree -strongly disagree }\end{array}$ \\
\hline 7 & $\begin{array}{l}\text { People who are important to me want me to do } 30 \text { minutes of moderate physical } \\
\text { activity at least } 5 \text { days a week. }\end{array}$ & $\begin{array}{l}\text { Strongly agree - agree - neither agree nor disagree - } \\
\text { disagree - strongly disagree }\end{array}$ \\
\hline 8 & $\begin{array}{l}\text { People who are important to me would expect me to do } 30 \text { minutes of moderate } \\
\text { physical activity at least } 5 \text { days a week. }\end{array}$ & $\begin{array}{l}\text { Strongly agree - agree - neither agree nor disagree - } \\
\text { disagree - strongly disagree }\end{array}$ \\
\hline 9 & $\begin{array}{l}\text { For me to do } 30 \text { minutes of moderate physical activity at least } 5 \text { days a week is } \\
\text { difficult }\end{array}$ & $\begin{array}{l}\text { Strongly agree - agree - neither agree nor disagree - } \\
\text { disagree - strongly disagree }\end{array}$ \\
\hline 10 & Doing 30 minutes of moderate physical activity at least 5 days a week is up to me & $\begin{array}{l}\text { Strongly agree - agree - neither agree nor disagree - } \\
\text { disagree - strongly disagree }\end{array}$ \\
\hline $11^{*}$ & If I want, I can to do 30 minutes of moderate physical activity at least 5 days a week & $\begin{array}{l}\text { Strongly agree - agree - neither agree nor disagree - } \\
\text { disagree - strongly disagree }\end{array}$ \\
\hline $12^{*}$ & I am going to do 30 minutes of moderate physical activity on .... day (days) & $0,1-2,3,4,5-7$ \\
\hline 13 & $\begin{array}{l}\text { How likely is it possible that you would make a decision to do } 30 \text { minutes moderate } \\
\text { physical activity at least } 5 \text { days a week in the next month? }\end{array}$ & $\begin{array}{l}\text { Very likely - likely - neither likely nor unlikely - unlikely - } \\
\text { very unlikely }\end{array}$ \\
\hline 14 & I expect to do 30 minutes of moderate physical activity at least 5 days a week & $\begin{array}{l}\text { Very likely - likely - neither likely nor unlikely - unlikely - } \\
\text { very unlikely }\end{array}$ \\
\hline $15^{*}$ & $\begin{array}{l}\text { The most of important others for me do } 30 \text { minutes of moderate physical activity at } \\
\text { least } 5 \text { days a week }\end{array}$ & $\begin{array}{l}\text { Strongly agree - agree - neither agree nor disagree - } \\
\text { disagree - strongly disagree }\end{array}$ \\
\hline 16 & $\begin{array}{l}\text { I would feel sick about not doing } 30 \text { minutes of moderate physical activity at least } 5 \\
\text { days a week }\end{array}$ & $\begin{array}{l}\text { Strongly agree - agree - neither agree nor disagree - } \\
\text { disagree - strongly disagree }\end{array}$ \\
\hline$\overline{17}$ & $\begin{array}{l}\text { I am under pressure from my family or friends to do } 30 \text { minutes of moderate } \\
\text { physical activity at least } 5 \text { days a week }\end{array}$ & $\begin{array}{l}\text { Strongly agree - agree - neither agree nor disagree - } \\
\text { disagree - strongly disagree }\end{array}$ \\
\hline 18 & $\begin{array}{l}\text { Doing } 30 \text { minutes of moderate physical activity at least } 5 \text { days a week would make } \\
\text { me.... }\end{array}$ & $\begin{array}{l}\text { Strongly satisfied - satisfied - neither satisfied nor } \\
\text { unsatisfied - unsatisfied - strongly unsatisfied }\end{array}$ \\
\hline 19 & I see myself as sporty & $\begin{array}{l}\text { Strongly agree - agree - neither agree nor disagree - } \\
\text { disagree - strongly disagree }\end{array}$ \\
\hline 20 & I see myself as fit and healthy & $\begin{array}{l}\text { Strongly agree - agree - neither agree nor disagree - } \\
\text { disagree - strongly disagree }\end{array}$ \\
\hline 21 & I see myself as a physically active person & $\begin{array}{l}\text { Strongly agree - agree - neither agree nor disagree - } \\
\text { disagree - strongly disagree }\end{array}$ \\
\hline 22 & Others might see me as a couch potato & $\begin{array}{l}\text { Strongly agree - agree - neither agree nor disagree - } \\
\text { disagree - strongly disagree }\end{array}$ \\
\hline
\end{tabular}

* Deleted items in the final version.

among panelists suggesting that the scale had a good content validity.

\section{Face validity}

The provisional scale was then administered to a sample of 5 diabetic women with different socio-demographic characteristics in order to assess clarity and readability of the items. In general there were no major problems in reading and understanding the items by women.
However, a few words were changed to meet women's considerations.

\section{The study and participants}

In order to test the scale in a wider context, a cross-sectional study carried out in the Charity Foundation for Special Diseases (CFFSD), in Tehran, Iran between November 2008 and July 2009. The inclusion criteria were: aged between 15 to 70 years, being literate, no 
history of diabetes complications, and mental and disabling disorders. To collect data, trained interviewers carried out face-to-face interviews.

\section{Statistical analysis Validity}

1. Construct validity: The dimensionality of the scale was determined by performing exploratory factor analysis (EFA) using the principal axis factoring and oblique rotation. Since correlation between factors was less than 0.3 , varimax rotation with Kaiser Normalization was selected [72]. In order to evaluate sampling adequacy to perform a satisfactory factor analysis, Kaiser-MeyerOlkin Measure of Sampling Adequacy (KMO) and Bartlett test was calculated. To determine the best structure, the eigenvalue greater than one and factor loading equal to or greater than 0.4 were applied [73].

2. Convergent validity: convergent validity was assessed performing item-scale correlations corrected for overlaps. Correlations were calculated using Pearson' correlation coefficient. It was expected that item scores would correlate higher with own hypothesized scale than other scales. Correlation values of 0.40 or above were considered satisfactory ( $r \geq 0.81-1$ as excellent, $0.61-0.80$ very good, 0.41 0.60 good, 0.21-0.40 fair, and 00-0.20 poor) [74].

\section{Reliability}

1. Internal consistency: The internal consistency of PAQDP was estimated by computing Cronbachs' alpha coefficient. The alpha values of 0.70 or above were considered satisfactory [74].

2. Test-retest: The test-retest reliability of the scale was estimated by intraclass correlation coefficient (ICC). The scale was re-administered to 16 individuals 1 month after the first completion. The following category was selected to interpret the agreement levels: 00-0.2 as slight, $0.21-0.40$ as fair, $0.41-0.60$ as moderate, 0.61-0.80 as substantial, and $0.81-1$ as almost perfect [75].

\section{Scoring}

The final version of the questionnaire is available [Additional file 1]. In addition details of scoring are provided. However, in summary each item is scored from 5 to 1 to provide row scores. Since three items on perceived difficulty, and capability of doing physical activity, and others' perceptions about one's mobility were negatively worded, scoring for these items (items 9, 10, and 22 in first version and 9, 10, and 19 in the final version) was reversed. A linear transformation was used to calculate scores ranging from 0 to 100; where higher scores indicate better perceptions about physical activity [Additional file 2].

\section{Ethical considerations}

The Ethics Committee of Tarbiat Modares University approved the study. All participants gave their permission by signing an informed consent form.

\section{Results}

A total of 127 diabetic patients participated in the study. The mean age of participants was $46.40(\mathrm{SD}= \pm 11.4)$ years. Most participants (86\%) enjoyed secondary education and were married (81\%). There were 109 patients with type 2 diabetes mellitus (86\%) and the remaining 18 patients with had type 1 diabetes (14\%). The results are shown in Table 3.

Exploratory factor analysis (EFA) was used to determine the underlying factor structure of the set of items. The calculated KMO was 0.73 and the Bartlett's test of sphericity was significant $(\mathrm{P}<0.0001)$. A six-factor solution with 19 items emerged based on eigenvalues higher than 1 and loading level of 0.4 or above. The six factors were named according to the underlying construct that related to the items: instrumental attitude, subjective norm, self-identity, perceived behavioral control, affective attitude, and intention. The six-factor solution explained $60.30 \%$ of the total variance of the hypothesized model. The detailed results are shown in Table 4.

Descriptive statistics including Cronbach's alpha, ICC, mean scores, and standard deviations for the PAQ-DP are presented in Table 5. The Cronbach's alpha for the subscales ranged from 0.54 to 0.82 . The intraclass correlation coefficient for the PAQ-DP subscales was

Table 3 Demographic and medical profile of the participants $(n=127)$

\begin{tabular}{lll}
\hline Age & No. (\%) \\
\hline Education & Year, Mean (SD) & $46.40 \pm 11.40$ \\
\hline & & \\
\hline & Primary & $28(22)$ \\
\hline Marital status & Secondary & $81(64)$ \\
\hline & Higher & $18(14)$ \\
\hline & Single & $12(9.40)$ \\
\hline & Married & $103(81)$ \\
\hline & Divorced or Widowed & $12(9.40)$ \\
\hline
\end{tabular}

Employment

\begin{tabular}{lll}
\hline & Housekeeper & $101(80.20)$ \\
\hline & Employed & $17(13.50)$ \\
\hline Student & $8(6.30)$ \\
\hline & & \\
\hline & Yes & $11(8.70)$ \\
\hline & No & $116(91.30)$
\end{tabular}

Diabetes type

\begin{tabular}{lll}
\hline & Type 1 & $18(14.20)$ \\
\hline & Type 2 & $109(85.80)$ \\
\hline BMI & Mean (SD) & $27.80 \pm 5$ \\
\hline Duration & Year, Mean (SD) & $8.50 \pm 6$ \\
\hline Physical activity & Min, Mean (SD) & $38.08(73.81)$ \\
\hline
\end{tabular}


Table 4 Results obtained from exploratory factor analysis

\begin{tabular}{|c|c|c|c|c|c|c|c|}
\hline & & F1 & F2 & F3 & $\mathrm{F} 4$ & F5 & F6 \\
\hline 1 & Beneficial - harmful & 0.79 & 0.08 & -0.01 & 0.05 & 0.09 & 0.13 \\
\hline 2 & Worthwhile - worthless & 0.74 & 0.09 & 0.18 & -0.04 & 0.14 & 0.09 \\
\hline 3 & Good - bad & 0.84 & 0.15 & 0.00 & 0.1 & 0.01 & -0.03 \\
\hline 4 & Enjoyable - boring & 0.45 & 0.08 & 0.15 & 0.20 & -0.09 & 0.48 \\
\hline 5 & Relaxing - stressful & 0.53 & 0.12 & 0.01 & 0.12 & -0.01 & 0.47 \\
\hline 6 & Think & 0.28 & 0.68 & -0.07 & 0.02 & 0.33 & -0.01 \\
\hline 7 & Want & 0.21 & 0.72 & 0.05 & -0.03 & 0.29 & 0.10 \\
\hline 8 & Expect & 0.29 & 0.63 & -0.01 & -0.07 & 0.29 & 0.08 \\
\hline 9 & $\begin{array}{l}\text { Capability of doing physical } \\
\text { activity }\end{array}$ & 0.06 & 0.02 & 0.09 & 0.88 & 0.08 & 0.00 \\
\hline 10 & $\begin{array}{l}\text { Difficulty of doing physical } \\
\text { activity }\end{array}$ & 0.03 & -0.03 & 0.17 & 0.56 & 0.15 & 0.14 \\
\hline 11 & If I want, I can & 0.11 & 0.30 & 0.17 & 0.29 & 0.01 & -0.04 \\
\hline 12 & I am going to do & 0.05 & -0.09 & 0.18 & 0.27 & 0.23 & -0.01 \\
\hline 13 & How likely & 0.00 & 0.12 & 0.10 & 0.16 & 0.67 & 0.10 \\
\hline 14 & I expect to do & 0.13 & 0.17 & 0.12 & 0.12 & 0.49 & 0.18 \\
\hline 15 & Important others do & -0.06 & 0.18 & 0.04 & 0.00 & -0.03 & 0.02 \\
\hline 16 & I feel sick & 0.01 & 0.03 & 0.05 & -0.02 & 0.08 & 0.43 \\
\hline 17 & I am under pressure & 0.10 & 0.57 & -0.13 & 0.05 & -0.12 & 0.27 \\
\hline 18 & Satisfied - unsatisfied & 0.14 & 0.23 & 0.05 & 0.06 & 0.27 & 0.60 \\
\hline 19 & Sporty & 0.05 & 0.01 & 0.68 & 0.14 & 0.18 & 0.07 \\
\hline 20 & Healthy & -0.01 & 0.19 & 0.65 & 0.25 & 0.02 & -0.03 \\
\hline 21 & Physically active person & 0.05 & 0.06 & 0.62 & 0.03 & 0.10 & 0.01 \\
\hline \multirow[t]{3}{*}{22} & Couch potato & 0.05 & -0.14 & 0.48 & 0.06 & -0.03 & 0.13 \\
\hline & Eigenvalue & 4.80 & 2.60 & 1.90 & 1.40 & 1.40 & 1.20 \\
\hline & Explained variance (\%) & 21.70 & 11.73 & 8.57 & 6.44 & 6.24 & 5.53 \\
\hline
\end{tabular}

F1: Instrumental attitude, F2: Subjective norm, F3: Self-identity, F4: Perceived behavioral control, F5: Intention, F6: Affective attitude

satisfactory (ICC ranged from 0.40 to 0.92 ). The correlation matrix is presented in Table 6. As expected the correlation between items belonging to any constructs of Theory of Planned Behavior was satisfactory.

\section{Discussion}

The purpose of this study was to develop a scale for assessing women's perceptions about physical activity and to test its psychometric properties. This scale was developed based on Theory of Planned Behavior framework. In Theory of Planned Behavior, each predictor may be measured directly e.g. by asking respondents about their overall attitude, or indirectly e.g. by asking respondents about specific behavioral beliefs and its outcome. Usually for developing a TPB-based questionnaire, it has been suggested that for direct measures one should use the same direct measures developed by Ajzen [57] and Francis [51]. For indirect (belief-based) measures it has been recommended to carry out an elicitation study to develop all predictor constructs in the TPB that are attitude; subjective norm; and perceived behavioral control. Direct and indirect approaches make different assumptions about the underlying cognitive structures and neither approach is perfect. When different methods are tapping the same construct, scores are expected to be positively correlated, so it is recommended that both be included in a TPB-based questionnaire [51]. Unfortunately, in this study, only direct measures of TPB were used.

As Francis et al. suggested, each construct should be measured using a minimum of three items. This will result in a minimum of 12 items for intention and direct measures of the predicting variables [51]. However, in the primarily draft of the questionnaire presented in this study, 22 items included. In fact according to Ajzen and Francis [51,57], attitude, subjective norm, and perceived behavioral control each contained two subscales (attitude: instrumental and affective; subjective norm: injunctive and descriptive; and perceived behavioral control: self-efficacy and controllability).

Exploratory factor analysis was led to remove three items from a total of original 22 items and the final 19item scale categorized in six factors explaining $60.3 \%$ of the variance observed. EFA with varimax rotation indicated that six factors including instrumental attitude, subjective norm, perceived behavioral control, affective attitude, self-identity, and intention can be extracted. As expected attitude was extracted with two subscales (instrumental and affective) but subjective norm and perceived behavioral control did load as single factors and expected subscales were not emerged separately.

Table 5 Descriptive statistics, Cronbach's alpha and intraclass correlation coefficient of the PAQ-DP subscales

\begin{tabular}{llllll}
\hline & No of items & Mean (SD)* & Skewness & Cronbach' alpha & ICC** \\
\hline Instrumental attitude & 4 & $88.80(11.80)$ & -1.70 & 0.82 & 0.79 \\
\hline Affective attitude & 3 & $79.60(13.70)$ & -0.80 & 0.54 & 0.56 \\
\hline Subjective norm & 4 & $75.40(16.50)$ & -0.70 & 0.76 & 0.92 \\
\hline Perceived behavioral control & 2 & $58.10(25.70)$ & -0.40 & 0.71 & 0.78 \\
\hline Self-identity & 4 & $49.50(20.20)$ & 0.00 & 0.71 & 0.73 \\
\hline Intention & 2 & $72(16.50)$ & -0.40 & 0.60 & 0.40 \\
\hline
\end{tabular}

*Scores range from 0 to 100 . Higher scores indicate better perceptions about physical activity.

**Intraclass Correlation Coefficient 
Table 6 Item-scale correlations of the Theory of Planned Behavior items and constructs

\begin{tabular}{|c|c|c|c|c|c|c|}
\hline \multirow[b]{2}{*}{ Factors } & \multicolumn{6}{|c|}{ Factors } \\
\hline & IA & AA & SN & PBC & SI & Int \\
\hline Instrumental attitude & 1 & $0.42^{* *}$ & $0.39^{* *}$ & 0.13 & 0.13 & $0.20^{*}$ \\
\hline Beneficial - harmful & $0.84^{* *}$ & $0.31^{* *}$ & $0.33^{* *}$ & 0.11 & 0.08 & 0.17 \\
\hline Worthwhile - worthless & $0.82^{* *}$ & $0.30^{* *}$ & $0.30^{* *}$ & 0.06 & $0.20^{*}$ & $0.19^{*}$ \\
\hline Good - bad & $0.86^{* *}$ & $0.22^{* *}$ & $0.33^{* *}$ & 0.12 & 0.06 & 0.13 \\
\hline Relaxing - stressful & $0.73^{* *}$ & $0.52^{* *}$ & $0.31^{* *}$ & 0.15 & 0.07 & 0.16 \\
\hline Affective attitude & $0.42^{* *}$ & 1 & $0.33^{* *}$ & $0.18^{*}$ & $0.19^{*}$ & $0.25 * *$ \\
\hline Enjoyable - boring & $0.53^{* *}$ & $0.64^{* *}$ & $0.25^{* *}$ & $0.23^{*}$ & $0.20^{*}$ & 0.10 \\
\hline I feel sick & 0.13 & $0.73^{* *}$ & 0.11 & 0.04 & 0.08 & 0.07 \\
\hline Satisfied - unsatisfied & $0.30^{* *}$ & $0.79 * *$ & $0.37^{* *}$ & 0.14 & 0.14 & $0.38^{* *}$ \\
\hline Subjective norm & $0.39^{* *}$ & $0.33^{* *}$ & 1 & 0.04 & 0.01 & $0.33^{* *}$ \\
\hline Think & $0.36^{* *}$ & $0.23^{*}$ & $0.78^{* *}$ & 0.07 & -0.01 & $0.32^{* *}$ \\
\hline Want & $0.32^{* *}$ & $0.28^{* *}$ & $0.83 * *$ & 0.05 & 0.11 & $0.33^{* *}$ \\
\hline Expect & $0.37^{* *}$ & $0.24^{* *}$ & $0.79 * *$ & -0.01 & 0.05 & $0.35^{* *}$ \\
\hline I am under pressure & $0.22^{*}$ & $0.27^{* *}$ & $0.75^{* *}$ & 0.02 & -0.08 & 0.11 \\
\hline Perceived behavioral control & 0.13 & $0.18^{*}$ & 0.04 & 1 & $0.28^{* *}$ & $0.26^{* *}$ \\
\hline Difficulty of doing physical activity & 0.13 & 0.13 & 0.03 & $0.88^{* *}$ & $0.23^{*}$ & $0.23^{* *}$ \\
\hline Capability of doing physical activity & 0.11 & $0.18^{*}$ & 0.04 & $0.89 * *$ & $0.27^{* *}$ & $0.23 * *$ \\
\hline Self-identity & 0.13 & $0.19^{*}$ & 0.01 & $0.28^{* *}$ & 1 & $0.23^{*}$ \\
\hline Sporty & 0.13 & $0.19^{*}$ & 0.01 & $0.21^{*}$ & $0.76^{* *}$ & $0.26^{* *}$ \\
\hline Healthy & 0.07 & 0.11 & 0.12 & $0.31^{* *}$ & $0.74^{* *}$ & 0.16 \\
\hline Physically active person & 0.10 & 0.09 & 0.04 & 0.15 & $0.75^{* *}$ & $0.20^{*}$ \\
\hline Couch potato & 0.07 & 0.15 & -0.13 & 0.16 & $0.67^{* *}$ & 0.04 \\
\hline Intention & $0.20^{*}$ & $0.25^{* *}$ & $0.33^{* *}$ & $0.26^{* *}$ & $0.23^{*}$ & 1 \\
\hline How likely & 0.11 & $0.18^{*}$ & $0.25^{* *}$ & $0.24 * *$ & $0.19^{*}$ & $0.85^{* *}$ \\
\hline I expect to do & $0.23^{* *}$ & $0.24^{* *}$ & $0.31^{* *}$ & $0.21^{*}$ & $0.20^{*}$ & $0.83^{* *}$ \\
\hline
\end{tabular}

${ }^{*} \mathrm{p}<.05,{ }^{* *} \mathrm{p}<.01$

IA: Instrumental attitude, AA: affective attitude, SN: Subjective norm, PBC: Perceived behavioral control, SI: Self-identity, Int: Intention,

Overall the internal consistency of the PAQ-DP was acceptable, although Cronbach's alpha for some dimensions were lower than 0.70 . However, there was no significant increase in the Cronbachs' alpha when any items were removed. This result may be due to the fact that fewer items were included in these dimensions. Also, small sample size, high homogeneity of the patients, and small variability of the scores might decreased alpha coefficients [71]. In addition, as Ajzen suggested, adapting items used in previous studies might produce measures with relatively low reliabilities and lead to an underestimate of the relations among the theory's constructs and of its predictive validity [57]. It seems that increasing the sample size, and increasing the number of items in some dimensions could further confirm the reliability of the scale. This result is very similar to those previously reported by Tan et al. [76] and Leung et al. [77].

There are some practical implications for developing a scale to measure diabetic patients' beliefs toward regular physical activity. Valid and reliable instruments are needed for designing and evaluating health programs based on behavior change theories of social and behavioral sciences [78]. Interventions to promote regular physical activity can target the beliefs that guide behavior. In other words, identifying beliefs could lead to development of effective programs and perhaps help to achieve healthy lifestyle for target populations. Health care providers who work with diabetic patients can use the measures to identify beliefs that promote regular physical activity and in turn intervene to delay or prevent diabetes complications. The PAQ-DP also could be a useful instrument for evaluating intervention effects by comparing the scores before and after patients' receiving various interventions; and for explaining the correlations of beliefs of diabetic patients with their exercise behavior.

The findings from this study should be interpreted with caution. This study had several inherent limitations: only female engaged in the study, sample size was 
relatively small, the reliability coefficients of some factors were not satisfactory. Also, only direct measures were used in the study. In addition 6 factors and 19 items means that most factors might not be quite deep. The future studies using this questionnaire could help to overcome these problems.

\section{Conclusion}

Overall, the study findings suggest that the PAQ-DP is a valid and reliable instrument for assessing beliefs of female diabetic patients regarding physical activity. The findings of the current study support the Ajzen's Theory of Planned Behavior. Further studies are recommended to confirm its application in clinical practice.

\section{Additional material}

\section{Additional file 1: Physical Activity Questionnaire for Diabetic}

Patients (PAQ-DP). This is the final version of the PAQ-DP that was developed by this study. The questionnaire could be used by other investigators providing that they cite this paper.

Additional file 2: Scoring Instruction for the PAQ-DP. This is an instruction for scoring the PAQ-DP.

\section{Acknowledgements}

We are grateful to the patients who participated in our study; and to the kind assistance of the staff members of the CFFSD' diabetes clinic and all people who kindly helped us in developing the scale in this research, especially Dr. John Spence of Alberta University, and others who helped us in this research.

\section{Author details}

'Department of Health Education, Tarbiat Modares University, Tehran, Iran. ${ }^{2}$ Department of Public Health, Ilam University of Medical Sciences, Ilam, Iran. ${ }^{3}$ Department of Biostatistics, Tarbiat Modares University, Tehran, Iran.

${ }^{4}$ Department of Mental Health, Institute for Health Sciences Research, ACECR, Tehran, Iran.

\section{Authors' contributions}

ZGh was the main investigator, collected the data, performed the statistical analysis, and drafted the manuscript. SHN supervised the research and contributed to all aspects of the study. FGH was advisor of the study and contributed to study design. EH helped in statistical analysis. AM helped as a consultant in study design, questionnaire, and revised the final article. All authors read and approved the final manuscript.

\section{Competing interests}

The authors declare that they have no competing interests.

Received: 3 July 2010 Accepted: 9 November 2010

Published: 9 November 2010

\section{References}

1. Shaw JE, Sicree RA, Zimmet PZ: Global estimates of the prevalence of diabetes for 2010 and 2030. Diabetes Res Clin Pract 2010, 87:4-14.

2. Warburton DE, Katzmarzyk PT, Rhodes RE, Shephard RJ: Evidence-informed physical activity guidelines for Canadian adults. Can J Public Health 2007, 98:S16-68

3. American Diabetes Association: Standards of medical care in diabetes2009. Diabetes Care 2009, 32:S13-S61.

4. Canadian Diabetes Association Clinical Practice Guidelines Expert Committee: Canadian Diabetes Association 2003 clinical practice guidelines for the prevention and management of diabetes in Canada. Can J Diabetes 2003, 27:S1-S152.

5. Thomas N, Alder E, Leese GP: Barriers to physical activity in patients with diabetes. Postgrad Med J 2004, 80:287-91.

6. National Cancer Institute, U.S.National Institutes of Health: Theory at a glance : a guide for health promotion practice., 2 2005, 15.

7. Michie S, Abraham C: Interventions to change health behaviors: evidence-based or evidence-inspired? Psychol Health 2004, 19:29-49.

8. Aizen I: From intentions to actions: a Theory of Planned Behavior. In Action control: from cognitions to behavior. Edited by: Kuhl J, Beckmann J. Berlin: Springer-Verlag; 1985:11-39.

9. Godin G, Kok G: The Theory of Planned Behavior: a review of its applications to health-related behaviors. Am J Health Promot 1996, 11:87-98.

10. Conner M, Sparks P: The Theory of Planned Behavior and health behaviors. In Predicting health behavior. Edited by: Conner M, Norman P. Buckingham: Open University Press; 1996:121-62.

11. Godin G: The Theories of Reasoned Action and Planned Behavior: overview of findings, emerging research problems and usefulness for exercise promotion. J Appl Sport Psychol 1993, 5:141-57.

12. Blue $\mathrm{CL}$ : The predictive capacity of the Theory of Reasoned Action and the Theory of Planned Behavior in exercise research: an integrated literature review. Res Nurs Health 1995, 18:105-21.

13. Hausenblas HA, Carron AV, Mack DE: Application of the Theories of Reasoned Action and Planned Behavior to exercise behavior: a metaanalysis. J Sport Exerc Psychol 1997, 19:36-51.

14. Hagger MS, Chatzisarantis NL, Biddle SJ: A meta-analytic review of the Theories of Reasoned Action and Planned Behavior in physical activity: predictive validity and the contribution of additional variables. I Sport Exerc Psychol 2002, 24:3-32.

15. Hausenblas HA, Downs DS: Prospective examination of the Theory of Planned Behavior applied to exercise behavior during women's first trimester of pregnancy. J Reprod Infant Psychol 2004, 22:199-210.

16. Courneya KS, Bobick TM: Integrating the theory of planned behavior with the processes and stages of change in the exercise domain. Psychol Sport Exerc 2000, 1:41-56

17. Downs DS, Hausenblas HA: Elicitation studies and the theory of planned behavior: a systematic review of exercise beliefs. Psychol Sport Exerc 2005, 6:1-31.

18. Downs DS, Hausenblas HA: The theories of reasoned action and planned behavior applied to exercise: A meta-analytic update. J Phys Act Health 2005, 2:76-97.

19. Hausenblas HA, Carron AV, Mack DE: Application of the theories of reasoned action and planned behavior to exercise behavior: A metaanalysis. J Sport Exerc Psychol 1997, 19:36-51.

20. Ajzen I, Madden T: Prediction of goal-directed behavior: attitudes, intentions, and perceived behavioral control. J Exp Social Psychiatry 1986 22:453-74.

21. Plotnikoff RC, Lippke S, Courneya K, Birkett N, Sigal R: Physical activity and diabetes: an application of the theory of planned behaviour to explain physical activity for Type 1 and Type 2 diabetes in an adult population sample. Psychol Health 2010, 25:7-23.

22. Davies CA, Mummery WK, Steele RM: The relationship between personality, theory of planned behaviour and physical activity in individuals with type II diabetes. Br J Sports Med 2010, 44:979-84.

23. Biddle SJ, Pearson N, Ross GM, Braithwaite R: Tracking of sedentary behaviors of young people: a systematic review. Prev Med 2010.

24. Biddle SJ, Gorely T, Marshall SJ, Murdey I, Cameron N: Physical activity and sedentary behaviours in youth: issues and controversies. J $R$ Soc Promot Health 2004, 24:29-33.

25. Jackson C, Smith RA, Conner M: Applying an extended version of the Theory of Planned Behaviour to physical activity. J Sports Sci 2003, 21:119-33.

26. Brownson RC, Baker EA, Housemann RA, Brennan LK, Bacak SJ: Environmental and policy determinants of physical activity in the United States. Am J Public Health 2001, 91:1995-2003.

27. O'dea JA: Why do kids eat healthful food? Perceived benefits of and barriers to healthful eating and physical activity among children and adolescents. J Am Diet Assoc 2003, 103:497-501.

28. Dubé MC, Valois P, Prud'homme D, Weisnagel SJ, Lavoie C: Physical activity barriers in diabetes: development and validation of a new scale. Diabetes Res Clin Pract 2006, 72:20-7. 
29. Dishman RK, Hales DP, Sallis JF, Saunders R, Dunn AL, Bedimo-Rung AL, Ring KB: Validity of social-cognitive measures for physical activity in middle-school girls. J Pediatr Psychol 2010, 35:72-88.

30. Fernance $D$, Lubans $D$, Morgan P: The development of scales for assessing social cognitive constructs relating to physical activity participation in adolescents. J Sci Med Sport 2010, 12:138-9.

31. Steinhardt MA, Dishman RK: Reliability and validity of expected outcomes and barriers for habitual physical activity. J Occup Med 1989, 31:536-46.

32. Wójcicki TR, White SM, McAuley E: Assessing outcome expectations in older adults: the multidimensional outcome expectations for exercise scale. J Gerontol B Psychol Sci Soc Sci 2009, 64:33-40

33. Saunders RP, Pate RR, Felton G, Dowda M, Weinrich MC, Ward DS, Parsons MA, Baranowski T: Development of questionnaires to measure psychosocial influences on children's physical activity. Prev Med 1997, 26:241-7.

34. Blue CL, Marrero DG, Black DR: Physical activity belief scales for diabetes risk: development and psychometric testing. Health Educ Behav 2008, 35:316-31.

35. Ajzen I: The Theory of Planned Behavior. Organ Behav Hum Decis Process 1991, 50:179-211.

36. Hamilton K, White KM: Extending the theory of planned behavior: the role of self and social influences in predicting adolescent regular moderate-to-vigorous physical activity. I Sport Exerc Psychol 2008, 30:56-74.

37. Belanger-Gravel A, Godin G: Key beliefs for targeted interventions to increase physical activity in children: analyzing data from an extended version of the theory of planned behaviour. Int J Pediatr 2010, 893854

38. Sparks P, Guthrie CA: Self-Identity and the theory of planned behavior: A useful addition or an unhelpful artifice? J Applied Social Psychol 1998, 28:1393-410

39. Azizi F, Guoya MM, Vazirian P, Dolatshati P, Habbibian S: Screening for type 2 diabetes in the Iranian national programme: a preliminary report. East Mediterr Health J 2003, 9:1122-7.

40. Sarrafzadegan N, Boshtam M, Rafiei M: Risk factors for coronary artery diseases in Isfahan. Eur J Public Health 1999, 1:20-6.

41. Meshkani R, Taghikhani M, Larijani B, Khatami S, Khoshbin E, Adeli K: The relationship between homeostasis model assessment and cardiovascular risk factors in Iranian subjects with normal fasting glucose and normal glucose tolerance. Clin Chim Acta 2006, 371:169-75.

42. Kelishadi R, Sadri G, Tavasoli AA, Kahbazi M, Roohafza HR, Sadeghi M, Khosravi A, Sabet B, Amani A, Ansari R, Alikhassy H: Cumulative prevalence of risk factors for atherosclerotic cardiovascular diseases in Iranian adolescents: IHHP-HHPC. J Pediatr (Rio J) 2005, 81:447-53.

43. Sarrafzadegan N, Kelishadi R, Baghaei A, Hussin Sadri G, Malekafzali H, Mohammadifard N, Rabiei K, Bahonar A, Sadeghi M, O'Laughlin J: Metabolic syndrome: an emerging public health problem in Iranian women: Isfahan Healthy Heart Program. Int I Cardiol 2008, 131:90-6.

44. Sallis JF: Seven-day physical activity recall. Med Sci Sports Exerc 1997, 29(Suppl 6):89-103.

45. Sallis JF, Haskell WL, Wood PD, Fortmann SP, Rogers T, Blair SN, Paffenberger RS Jr: Physical activity assessment methods in Five-City Project. Am J Epidemiol 1985, 121:91-106.

46. Courneya KS, Nigg CR, Estabrooks PA: Relationships among the Theory of Planned Behavior, Stages of Change, and exercise behavior in older persons over a three year period. Psychol Health 1998, 13:355-67.

47. Courneya KS, Bobick TM, Schinke RJ: Does the Theory of Planned Behavior mediate the relation between personality and exercise behavior? Basic Appl Soc Psych 1999, 21:317-24.

48. Courneya KS, Bobick TM: Integrating the Theory of Planned Behavior with the processes and stages of change in the exercise domain. Psychol Sport Exerc 2000, 1:41-56

49. Blue CL, Wilbur J, Marston-Scott MV: Exercise among Blue-Collar workers: application of the Theory of Planned Behavior. Res Nurs Health 2001, 24:481-93.

50. Rhodes RE, Courneya KS: Modelling the Theory of Planned Behavior and past behavior. Psychol Health Med 2003, 8:57-69.

51. Francis JJ, Eccles MP, Johnston M, Walker A, Grimshaw J, Foy R, Kaner EFS, Smith L, Bonetti D: Constructing questionnaires based on the Theory of Planned Behaviour: A manual for health services researchers. Newcastle: Centre for Health Services Research; 2004, 1-42.
52. Hausenblas HA, Downs DS: Prospective examination of the Theory of Planned Behavior applied to exercise behavior during women's first trimester of pregnancy. J Reprod Infant Psychol 2004, 22:199-210.

53. Rhodes RE, Courneya KS: Differentiating motivation and control in the Theory of Planned Behavior. Psychol Health Med 2004, 9:205-15.

54. Prapavessis H, Maddison R, Ruygrok PN, Bassett S, Harper T, Gillanders L: Using Theory of Planned Behavior to understand exercise motivation in patients with congenital heart disease. Psychol Health Med 2005, 10:335-43.

55. Rhodes RE, Plotnikoff RC: Can current physical activity act as a reasonable proxy measure of future physical activity? evaluating cross-sectional and passive prospective designs with the use of social cognition models. Prev Med 2005, 40:547-555.

56. Walsh JJ, Fonseca RSDA, Banta A: Watching and participating in exercise videos: a test of the Theory of Planned Behavior, conscientiousness, and the role of implementation intentions. Psychol Health 2005, 20:729-41.

57. Ajzen I: Constructing a TPB questionnaire: conceptual and methodological consideration, 2006.[http://www.uni-bielefeld.de/ikg/zick/ ajzen\%20construction\%20a\%20tpb\%20questionnaire.pdf].

58. Courneya KS, Conner M, Rhodes RE: Effects of different measurement scales on the variability and predictive validity of the "two-component" model of the Theory of Planned Behavior in the exercise domain. Psychol Health 2006, 21:557-70.

59. Kaiser FG: A moral extension of the Theory of Planned Behavior: norms and anticipated feelings of regret in conservationism. Pers Individ Dif 2006, 41:71-81.

60. White KM, Terry DJ, Troup C, Rempel LA: Behavioral, normative and control beliefs underlying low-fat dietary and regular physical activity behaviors for adults diagnosed with type 2 diabetes and/or cardiovascular disease. Psychol Health Med 2007, 12:485-94.

61. Hill C, Abraham C, Wright DB: Can theory-based messages in combination with cognitive prompts promote exercise in classroom settings? Soc SCi Med 2007, 65:1049-58.

62. Blue CL: Does the Theory of Planned Behavior identify diabetes-related cognitions for intention to be physically active and eat a healthy diet? Public Health Nurs 2007, 24:141-50.

63. Jones LW, Guill B, Keir ST, Carter K, Friedman HS, Bigner DD, Reardon DA: Using the Theory of Planned Behavior to understand the determinants of exercise intention in patients diagnosed with primary brain cancer. Psychooncology 2007, 16:232-40.

64. Plotnikoff RC, Courneya KS, Trinh L, Karunamuni N, Sigal RJ: Aerobic physical activity and resistance training: an application of the Theory of Planned Behavior among adults with type 2 diabetes in a random, national sample of Canadians. Int J Behav Nutr Phys Act 2008, 5:61-75.

65. Parrott MW, Tennant LK, Olejnik S, Poudevigne MS: Theory of Planned Behavior: implications for an email-based physical activity intervention. Psychol Sport Exerc 2008, 9:511-26.

66. Chatzisarantis NLD, Hagger MS, Brickell T: Using the construct of perceived autonomy support to understand social influence within the Theory of Planned Behavior. Psychol Sport Exerc 2008, 9:27-44.

67. Boudreau F, Godin G: Understanding physical activity intentions among French Canadians with type 2 diabetes: an extension of Ajzen's Theory of Planned Behavior. Int I Behav Nutr Phys Act 2009, 6:35-46.

68. Rhodes RE, Blanchard CM, Matheson DH, Coble J: Disentangling motivation, intention, and planning in the physical activity domain. Psychol Sport Exerc 2006, 7:15-27.

69. Lawshe $\mathrm{CH}$ : A quantitative approach to content validity. Personal Psychology 1975, 28:563-75.

70. Grant JS, Davis LL: Focus on quantitative methods: selection and use of content experts for instrument development. Res Nurs Health 1997, 20:269-74.

71. Polit DF, Beck CT: Nursing research: principles and methods. 46 edition. Philadelphia: Lippincott; 2004, 416-45.

72. Kline P: An easy guide to factor analysis New York: Routledge; 1993.

73. Sharma S: Applied multivariate techniques New York: John Wiley; 1996.

74. Nunnally JC, Bernstein IH: Psychometric theory New York: McGraw-Hill Inc:; 1994.

75. Landis JR, Koch GG: The measurement of observer agreement for categorical data. Biometrics 1977, 33:159-74 
76. Tan MY: The relationship of health beliefs and complication prevention behaviors of Chinese individuals with type 2 diabetes mellitus. Diabetes Res Clin Pract 2004, 66:71-7.

77. Leung SF, Lee KL, Lee SM, Leung SC, Hung WS, Lee WL, Leung YY, Lib MW, Tse TK, Wong HK, Wong YN: Psychometric properties of the SCOFF questionnaire (Chinese version) for screening eating disorders in Hong Kong secondary school students: A cross-sectional study. Int I Nurs Stud 2008, 46:239-47.

78. Blue $C L$, Marrero DG: Psychometric properties of the healthful eating belief scales for persons at risk of diabetes. J Nutr Educ Behav 2006, 38:1341-42.

\section{Pre-publication history}

The pre-publication history for this paper can be accessed here: http://www.biomedcentral.com/1471-2288/10/104/prepub

\section{doi:10.1186/1471-2288-10-104}

Cite this article as: Ghazanfari et al:: Development and psychometric properties of a belief-based Physical Activity Questionnaire for Diabetic Patients (PAQ-DP). BMC Medical Research Methodology 2010 10:104.

\section{Submit your next manuscript to BioMed Central and take full advantage of:}

- Convenient online submission

- Thorough peer review

- No space constraints or color figure charges

- Immediate publication on acceptance

- Inclusion in PubMed, CAS, Scopus and Google Scholar

- Research which is freely available for redistribution

Submit your manuscript at www.biomedcentral.com/submit 